\title{
Uji Potensi Antiinflamasi Ekstrak Etanol Daun Bambu-Bambu (Polygonum pulchrum Blume) Dengan Metode Stabilisasi Membran Sel Darah Merah Secara In Vitro
}

\author{
F. I. Armadany ${ }^{1,{ }^{*},}$, Wahyuni ${ }^{1}$, M.Ardianti ${ }^{1}$, A.N. T.A Mallarangeng ${ }^{1,2}$ \\ ${ }^{1}$ Fakultas Farmasi, Universitas Halu Oleo, Kendari-Sulawesi Tenggara \\ ${ }^{2}$ Fakultas SAINTEK, Jurusan Farmasi, Institiut Teknologi dan Kesehatan Avicenna, Kendari-Sulawesi Tenggara \\ *Email korespondensi : feryia74@gmail.com
}

(Submit 15/03/2019, Revisi 05/09/2019, Diterima 20/12/2019)

\begin{abstract}
Abstrak
Inflamasi merupakan rangkaian perubahan kompleks dalam jaringan akibat cedera yang disebabkan oleh bakteri, trauma, zat kimia, panas dan nyeri.Tumbuhan bambubambu (Polygonum pulchrum Blume) adalah salah satu jenis tumbuhan perennial yang mengandung senyawa bioaktif dengan beberapa potensi aktivitas farmakologi, diantaranya sebagai antiinflamasi. Penelitian ini bertujuan untuk mengetahui kandungan metabolit sekunder dan uji aktivitas antiinflamasi dari daun bambu-bambu (Polygonum pulchrum Blume) dengan menggunakan metode stabilisasi membran sel darah merah secara in vitro. Kandungan metabolit sekunder diidentifikasi menggunakan metode skrining fitokimia secara kualitatif berdasarkan reaksi pengujian warna. Pengujian potensi aktivitas antiinflamasi dilakukan dengan metode stabilisasi membran sel darah merah secara In Vitro yaitu melalui kemampuan daya hambat ekstrak etanol daun bambu-bambu (Polygonum pulchrum Blume) terhadap lisis sel darah merah akibat induksi larutan hipotonis yang kemudian dibandingkan dengan kontrol positif yaitu natrium diklofenak. Hasil penelitian menunjukkan bahwa ekstrak etanol Polygonum pulchrum Blume positif mengandung flavonoid, tanin, dan saponin. Nilai persentase stabilitas sel darah merah yang dimiliki oleh ekstrak etanol daun Polygonum pulchrum dengan konsentrasi 50, 100, 200, 400, 800, dan 1600 ppm berturut-turut adalah $58,13 \% ; 67,3 \% ; 75,72 \% ; 83,28 \% ; 87,05 \%$; dan 92,99\%. Adapun stabilitas persentase yang dimiliki oleh kontrol positif dengan konsentrasi 50, 100, 200, 400, 800, dan 1600 ppm adalah 58,99\%; 66,38\%; 73,24\%; 80,58\%; 82,95\% dan 86,73\%. Ekstrak etanol daun bambu-bambu (Polygonum pulchrum Blume) pada semua variasi konsentrasi memiliki potensi aktivitas dalam menstabilkan membran sel darah merah.
\end{abstract}

Kata kunci: Antiinflamasi, membran sel darah merah, Polygonum pulchrum Blume

\section{Outline}

- Pendahuluan

- Metode

- Hasil dan Pembahasan

- Kesimpulan

- Ucapan Terima Kasih

- Daftar Pustaka 


\section{Pendahuluan}

Jumlah tanaman obat di Indonesia merupakan 90\% dari jumlah tanaman obat yang ada di kawasan Asia ${ }^{1}$. Dewasa ini masyarakat banyak yang lebih memilih pengobatan dengan menggunakan tanaman obat dibandingkan dengan obat-obat kimia. Namun penggunaan tanaman obat tersebut harus diikuti dengan pengetahuan tentang khasiat tanaman obat tersebut di dalam tubuh, agar tanaman obat yang dikonsumsi memiliki pengaruh yang signifikan terhadap kesembuhan. Salah satu contoh khasiat tanaman obat adalah sebagai antiinflamasi ${ }^{2}$. Polygonum pulchrum Blume merupakan tumbuhan yang terkenal menghasilkan berbagai metabolit sekunder termasuk flavonoid, triterpenoid, antrakuinon, kumarin, fenilpropanoid, lignan, sesquiterpenoid, stilben dan $\operatorname{tanin}^{3}$.

Beberapa penelitian mengenai kandungan kimia dari tanaman Polygonum pulchrum Blume telah dilakukan untuk mengetahui aktivitas farmakologi dari tanaman tersebut. Penelitian oleh Vlientinck $\mathrm{dkk}^{4}$ menunjukkan bahwa ekstrak tanaman Polygonum pulchrum Blume memiliki aktivitas sebagai antivirus, antibakteri dan antifungi. Penelitian selanjutnya yang dilakukan oleh Johnson ${ }^{5}$ menunjukkan bahwa tanaman Polygonum pulchrum Blume memiliki aktivitas sebagai antibakteri. Penelitian yang dilakukan oleh Sahidin $\mathrm{dkk}^{6}$ menunjukkan bahwa ekstrak batang Polygonum pulchrum Blume mengandung salah satu senyawa golongan triterpen steroid yang berperan aktif sebagai antioksidan. Penelitian yang dilakukan oleh $\mathrm{Poko}^{7}$ pada ekstrak etanol tumbuhan Polygonum pulchrum Blume menunjukkan dosis yang optimal dan efektif sebagai anthiperlipidemia. Penelitian berikutnya dilakukan oleh Sadino ${ }^{8}$ menunjukkan ekstrak daun Polygonum memiliki aktivitas sebagai antioksidan. Penelitian yang telah dilakukan di atas, merupakan penelitian yang memaparkan potensi efek farmakologi dari tanaman Polygonum pulchrum Blume. Namun dari serangkaian penelitian tersebut, belum dilakukan penelitian untuk mengetahui potensi dari Polygonum pulchrum Blume sebagai antiinflamasi.

Salah satu metode yang dapat digunakan untuk pengujian antiinflamasi yaitu menggunakan metode stabilisasi sel darah merah (sel darah merah) manusia secara invitro. Metode ini digunakan karena sel darah merah mirip dengan membran lisosom yang dapat mempengaruhi proses inflamasi, sehingga jika kestabilan sel darah merah terjaga maka stabilisasi membran lisosom juga akan terjaga. Hal ini ditunjukan melalui stabilisasinya terhadap sel darah merah yang di induksi dengan larutan hipotonik sehingga tidak terjadi lisis pada sel dan mencegah lepasnya hemoglobin $(\mathrm{Hb})^{9}$. Oleh karena itu, dalam penelitian ini dilakukan uji aktivitas antiinflamasi ekstrak etanol daun Polygonum pulchrum Blume dengan metode stabilisasi sel darah merah secara in-vitro.

\section{Metode}

\section{A. Bahan}

Daun tumbuhan bambu-bambu (Polygonum pulchrum Blume), $\mathrm{NaCl}$, dinatrium hidrogen fosfat $\left(\mathrm{Na}_{2} \mathrm{HPO}_{4} \cdot 2 \mathrm{H}_{2} \mathrm{O}\right)$, natrium dihidrogen fosfat $\left(\mathrm{NaH}_{2} \mathrm{PO}_{4} \cdot \mathrm{H}_{2} \mathrm{O}\right)$, Natrium diklofenak, $\mathrm{HCl}, \mathrm{FeCl}_{3}(1 \%)$, pereaksi Lieberman-Bourchard, pereaksi Dragendorf, etanol 96\%, serbuk magnesium, asam sulfat, reagen sianmet hemoglobin, pereaksi eosin, aquades, spoit, aluminium foil, kertas saring. 


\section{B. Metode}

1. Pembuatan Ekstrak Tanaman

Sampel daun tumbuhan Polygonum pulchrum Blume diperoleh dan dikumpulkan di Kelurahan Kambu, Kota Kendari Provinsi Sulawesi Tenggara. Sampel disortasi basah dan kering kemudian dikering anginkan lalu dihaluskan hingga diperoleh serbuk simplisia. Selanjutnya serbuk simplisia diekstraksi dengan metode maserasi dengan pelarut etanol $96 \%$.

\section{Skrining Fitokimia}

Skrining fitokimia dilakukan dengan metode reaksi warna untuk menguji adanya alkaloid, flavonoid, saponin, tannin, dan terpenoid.

\section{Karakterisasi Simplisia}

Karakterisasi simplisia dilakukan dengan melihat parameter spesifik meliputi pemeriksaan organoleptik, penentuan kadar sari larut air dan sari larut etanol, dan parameter non spesifik meliputi penentuan kadar air dan kadar abu.

\section{Uji Aktivitas Antiinflamasi Metode Stabilisasi Membran Sel darah merah}

i. Pembuatan Larutan yang dibutuhkan

a. Pembuatan dapar fosfat $\mathrm{pH} 7,4(0,15 \mathrm{M})$

$121,5 \mathrm{~mL}$ larutan $\mathrm{Na}_{2} \mathrm{HPO}_{4} \cdot 2 \mathrm{H}_{2} \mathrm{O}(0,15 \mathrm{M})$ dicampurkan dengan $28,5 \mathrm{~mL}$ larutan $\mathrm{NaH}_{2} \mathrm{PO}_{4} \cdot 2 \mathrm{H}_{2} \mathrm{O}(0,15 \mathrm{M})$ dan disterilisasi dengan autoklaf pada suhu $115^{\circ} \mathrm{C}$ selama 30 menit.

b. Pembuatan Hiposalin

Larutan hiposalin dibuat kemudian disterilisasi dengan autoklaf pada suhu $115^{\circ} \mathrm{C}$ selama 30 menit.

c. Pembuatan Seri Konsentrasi Ekstrak dan Na diklofenak

Dibuat larutan induk ekstrak dan kontrol (Na diklofenak) dalam larutan isosalin (2000 $\mathrm{ppm}$ ). Kemudian masing-masing larutan diencerkan menjadi beberapa seri konsentrasi $(50,100,200,400,800,1600$ ppm).

\section{ii. Pembuatan Suspensi Sel darah merah}

Darah yang telah diperoleh dari volunteer (pendonor) dimasukkan ke dalam tabung sentrifus berisi larutan alsever steril sebanyak $10 \mathrm{~mL}$. Selanjutnya disentrifugasi dengan kecepatan $3.000 \mathrm{rpm}$ selama 10 menit. Supernatan yang terbentuk dipisahkan. Endapan sel-sel darah dicuci dengan larutan isosalin dan disentrifugasi kembali. Proses dilakukan beberapa kali hingga supernatan jernih. Kemudian dibuat suspensi sel darah merah $10 \%$ dengan mencampurkan $2 \mathrm{~mL}$ darah merah dengan $18 \mathrm{~mL}$ larutan isosalin.

iii. Pengujian Aktivitas Ekstrak Terhadap Stabilisasi Membran Sel darah merah

a. Pembuatan Larutan Kontrol Negatif Larutan blanko terdiri dari $1 \mathrm{~mL}$ dapar fosfat $\mathrm{pH} 7,4(0,15 \mathrm{M}), 2 \mathrm{~mL}$ hiposalin, $1 \mathrm{~mL}$ larutan isosalin dan $0,5 \mathrm{~mL}$ suspensi sel darah merah.

b. Pembuatan Larutan uji

Larutan uji terdiri dari $1 \mathrm{~mL}$ dapar fosfat $\mathrm{pH} 7,4(0,15 \mathrm{M}), 2 \mathrm{~mL}$ hiposalin, $0,5 \mathrm{~mL}$ suspensi sel darah merah dan $1 \mathrm{~mL}$ larutan sampel.

c. Pembuatan Larutan Kontrol Positif

Larutan kontrol positif terdiri dari $1 \mathrm{~mL}$ dapar fosfat $\mathrm{pH}$ 7,4 (0,15 M), $2 \mathrm{~mL}$ hiposalin, $0,5 \mathrm{~mL}$ suspensi sel darah merahdan $1 \mathrm{~mL}$ larutan Na diklofenak (Shailesh, 2011). 
d. Pengukuran Stablisitas Sel darah merah

Setiap larutan diinkubasi pada $56^{\circ} \mathrm{C}$ selama 30 menit dan disentrifugasi pada $5000 \mathrm{rpm}$ selama 10 menit. Cairan supernatan yang didapat diambil dan kandungan hemoglobinnya diperhitungkan dengan menggunakan photometer 5010 pada panjang gelombang $546 \mathrm{~nm}$.

Persen stabilitas sel darah merah dapat dihitung dengan rumus, sebagai berikut (Chippada,dkk : 2011):

$\%$ Hemolisis $=\frac{\text { Kadar hemoglobin larutan uji uji }}{\text { Kadar hemoglobin } \text { kontrol negatif }} \times 100$
$\%$ Stabilitas $=100-\frac{\text { Kadar hemoglobin larutan uji }}{\text { Kadar hemoglobin kontrol negatif }} \times 100$

\section{Hasil dan Pembahasan}

\section{A. Hasil}

1. Skrining Fitokimia

Senyawa kimia yang dianalisis pada daun Polygonum pulchrum Blume adalah senyawa golongan alkaloid, flavonoid, tanin, saponin dan terpenoid. Hasil skrining fitokimia daun Polygonum pulchrum Blume disajikan pada Tabel 1.

Tabel 1. Skrining fitokimia ekstrak etanol daun Polygonum pulchrum Blume

\begin{tabular}{|c|c|c|c|c|c|}
\hline Uji Fitokimia & Pereaksi & Rujukan & Hasil & Kesimpulan \\
\hline Alkaloid & Dragendorf & $\begin{array}{c}\text { Terbentuk endapan coklat } \\
\text { atau merah hingga jingga }\end{array}$ & $\begin{array}{c}\text { Tidak terbentuk } \\
\text { endapan }\end{array}$ & Hasil (-) \\
\hline Flavonoid & $\mathrm{HCl}+\mathrm{Mg}$ & $\begin{array}{c}\text { Terbentuk warna merah atau } \\
\text { merah jingga }\end{array}$ & $\begin{array}{c}\text { Terbentuk warna } \\
\text { merah }\end{array}$ & Hasil (+) \\
\hline Tannin & $\mathrm{FeCl}_{3}$ & $\begin{array}{c}\text { Terbentuk warna hijau ungu } \\
\text { atau kehitaman }\end{array}$ & $\begin{array}{c}\text { Terbentuk warna } \\
\text { hijau kehitaman }\end{array}$ & Hasil (+) \\
\hline Saponin & Air & $\begin{array}{c}\text { Terbentuk busa setinggi } 1-10 \\
\text { cm dan stabil tidak kurang } \\
\text { dari } 10 \text { menit }\end{array}$ & Terbentuk busa & Hasil (+) \\
\hline Terpenoid & $\begin{array}{c}\text { Lieberman } \\
\text { Burchard }\end{array}$ & Terbentuk warna coklat & Tidak terbentuk & Hasil (-) \\
\hline
\end{tabular}

\section{Karakterisasi Simplisia}

Karakterisasi simplisia dilakukan untuk melihat parameter spesifik (pemeriksaan organoleptik, kadar sari larut air dan kadar sari larut etanol) dan parameter non spesifik (kadar air dan kadar abu). Hasil karakterisasi disajikan pada Tabel 2.

Tabel 2. Hasil karakterisasi simplisia Polygonum pulchrum Blume

\begin{tabular}{ll}
\multicolumn{1}{c|}{ Jenis karakterisasi } & Hasil \\
\hline $\begin{array}{l}\text { Organoleptis } \\
\text { Bentuk }\end{array}$ & \\
Warna & Lanset \\
Bau & Hijau \\
Kadar air & Khas \\
Kadar abu & $9,03 \%$ \\
Kadar sari larut etanol & $4,8 \%$ \\
Kadar sari larut air & $22,06 \%$ \\
\hline
\end{tabular}




\section{Stabilisasi Sel darah merah}

Hasil persentase stabilitas ekstrak etanol daun Polygonum dan natrium diklofenak sebagai pembanding menunjukkan semakin meningkatnya konsentrasi ekstrak maka meningkat pula potensi ekstrak dalam menstabilisasi sel darah merah, artinya potensi antiinflamasinya juga semakin meningkat. Hal ini dapat dilihat pada Tabel 3.

Tabel 3. Nilai \% Stabilitas Ekstrak Daun Polygonum pulchrum Blume dan Natrium Diklofenak

\begin{tabular}{|l|c|c|}
\hline Konsentrasi & $\begin{array}{c}\text { \% Stabilitas Ekstrak Daun } \\
\text { Polygonum pulchrum Blume }\end{array}$ & $\begin{array}{c}\text { \% Stabilitas Natrium } \\
\text { Diklofenak }\end{array}$ \\
\hline $\mathbf{5 0} \mathrm{ppm}$ & $58,13 \%$ & $58,99 \%$ \\
\hline $\mathbf{1 0 0} \mathrm{ppm}$ & $67,3 \%$ & $66,38 \%$ \\
\hline $\mathbf{2 0 0} \mathrm{ppm}$ & $75,72 \%$ & $73,24 \%$ \\
\hline $\mathbf{4 0 0} \mathrm{ppm}$ & $83,28 \%$ & $80,58 \%$ \\
\hline $\mathbf{8 0 0} \mathrm{ppm}$ & $87,05 \%$ & $82,95 \%$ \\
\hline $1600 \mathrm{ppm}$ & $92,99 \%$ & $87,05 \%$ \\
\hline
\end{tabular}

\section{B. Pembahasan}

Skrining fitokimia bertujuan untuk mendapatkan informasi golongan senyawa metabolit sekunder yang terdapat didalam daun Polygonum pulchrum Blume. Hasil penelitian menunjukkan bahwa daun Polygonum pulchrum Blume mengandung flavonoid, tannin dan saponin. Ketiga senyawa ini diduga berperan dalam menstabilkan sel darah merah. Flavonoid memiliki kemampuan memblok siklooksigenase, asam arakhidonat sehingga sintesis prostaglandin terhambat. Saponin dan tanin memiliki komponen untuk mengikat kation, sehingga menstabilkan membran sel darah merah dan makromolekul lainnya ${ }^{9}$.

Senyawa yang memiliki kemampuan untuk menstabilkan membran dikenal dapat mengganggu proses awal dari fase inflamasi yaitu pelepasan enzim fosfolipase A2. Pelepasan fosfolipase A2 dapat menyebabkan kerusakan jaringan dan memicu terbentuknya radikal bebas. Fosfolipase A2 berfungsi mengubah fosfolipid dalam membran sel menjadi asam arakidonat, yang sangat efektif dan cepat dimetabolisme oleh enzim siklooksigenase menjadi prostaglandin. Prostaglandin merupakan mediator yang dapat menyebabkan terjadinya inflamasi.

Hasil penelitian Sadino ${ }^{8}$ sebelumnya telah menunjukkan bahwa daun Polygonum pulchrum Blume memiliki aktivitas antioksidan. Aktivitas antiinflamasi erat hubungannya dengan aktivitas antioksidan. Antioksidan ini dapat mencegah terjadinya stress oksidatif yang mempengaruhi kestabilan sel darah merah ${ }^{10}$. Sel darah merah sangat rentan terhadap radikal bebas (reactive oxygen species/ROS), oleh karena itu diperlukan senyawa antioksidan dan antiinflamasi yang dapat melindungi sel. Senyawa antioksidan akan menghambat atau memperlambat oksidasi melalui penangkapan radikal bebas, sedangkan senyawa antiinflamasi akan menstabilkan membran sel. Stress oksidatif terjadi karena kadar radikal bebas (reactive oxygen species/ROS) yang terlalu tinggi tidak mampu dinetralisir oleh antioksidan sehingga akan terjadi keadaan yang tidak seimbang antara radikal bebas (reactive oxygen species/ROS) dan antioksidan. Kelebihan dari radikal bebas (reactive oxygen species/ROS) dapat bereaksi dengan lipid, protein dan asam nukleat sehingga memicu kerusakan membran yang ditandai dengan hemolisis ${ }^{11}$. 
Sel darah merah merupakan salah satu komponen darah yang jumlahnya paling banyak dalam susunan komponen darah manusia. Darah yang digunakan dalam penelitian ini adalah darah yang diperoleh dari sukarelawan sehat yang tidak mengkonsumsi obat AINS selama dua minggu yang diambil secara langsung oleh tenaga medis di Rumah Sakit Palang Merah Indonesia Kendari. Sel darah merah yang normal memiliki bentuk bikonkaf, tidak memiliki inti dan mengandung hemoglobin yang merupakan representasi warna merah dalam darah. Bentuk dari sel darah merah ini dapat dilihat dengan menggunakan mikroskop (Gambar 1). Sel darah merah yang normal juga dapat dilihat melalui stabilitas membrannya. Bila sel darah merah terpapar zat berbahaya seperti larutan hipotonik atau berada di dalam media yang dipanaskan maka akan terjadi hemolisis. Pada keadaan hemolisis, maka membran sel dalam keadaan luka sehingga sel lebih rentan terhadap radikal bebas yang dapat mengakibatkan peroksidasi lipid dan akan mengakibatkan kerusakan sel yang lebih $\operatorname{parah}^{11}$.



Gambar 1. Sel darah merah yang telah ditambah ekstrak etanol daun Polygonum pulchrum Blume

Stabilisasi dari sel darah merah digunakan sebagai metode untuk mengetahui aktivitas antiinflamasi secara invitro. Hal ini dikarenakan sel darah merah mirip dengan membran lisosom yang dapat mempengaruhi proses inflamasi sehingga stabilitas lisosom penting dalam membatasi respon inflamasi, yaitu dengan cara mencegah pelepasan enzim dari dalam lisosom selama proses inflamasi berlangsung. Dengan demikian, stabilisasi sel darah merah yang diinduksi dengan larutan hipotonik dapat digunakan sebagai ukuran untuk mengindikasikan stabilisasi dari membran lisosom ${ }^{12}$. 
Hasil analisis larutan uji yang memiliki aktivitas antiinflamasi dapat dilihat dari besar kecilnya kadar hemoglobin yang terdapat pada larutan uji. Kadar hemoglobin yang kecil menandakan lisis yang terjadi juga sedikit dan sebaliknya jika kadar hemoglobinnya besar maka lisis yang terjadi juga banyak. Aktivitas antiinflamasi dari ekstrak daun Polygonum pulchrum Blume tidak hanya dilihat dari kadar hemoglobinnya tetapi dapat pula dilihat dari persen stabilitasnya.

Nilai persen stabilisasinya meningkat seiring bertambahnya konsentrasi disebabkan karena kandungan senyawa penstabil membran sel darah merah dalam setiap konsentrasi semakin meningkat. Data aktivitas antiinflamasi yang telah diperoleh dari masing-masing konsentrasi ekstrak dan natrium diklofenak dilakukan uji statistik menggunakan SPSS (Statistical Package For Social Science) ANOVA satu arah dilanjutkan dengan uji Beda Nyata Terkecil (BNT/LSD) dengan metode Tukey kemudian dilakukan pengujian menggunakan homogeneous subsets untuk mengetahui sampel yang tidak berbeda secara signifikan atau identik, Hasil analisis menggunakan homogeneous subsets menunjukkan bahwa ekstrak dengan konsentrasi 400 ppm, 800 ppm dan 1600 ppm identik dengan natrium diklofenak konsentrasi 1600 ppm. Oleh karena itu ekstrak daun Polygonum pulchrum Blume dapat berpotensi sebagai antiinflamasi.

\section{Kesimpulan}

a. Kandungan metabolit sekunder yang terdapat dalam daun tumbuhan bambu-bambu (Polygonum pulchrum Blume) adalah flavonoid,tanin dan saponin.

b. Daun tumbuhan bambu-bambu (Polygonum pulchrum Blume) memiliki kemampuan antiinflamasi yang diukur menggunakan metode stabilisasi sel darah merah. Persentase stabilitas ekstrak etanol daun tumbuhan bambu-bambu (Polygonum pulchrum Blume) yaitu pada $50 \mathrm{ppm}(58,13 \%), 100 \mathrm{ppm}(67,3 \%), 200 \mathrm{ppm}$ $(75,72 \%), 400$ ppm (83,28\%), 800 ppm (87,05\%) dan 1600 ppm (92,99\%) menunjukkan bahwa semakin tinggi konsentrasi yang digunakan maka semakin tinggi pula aktivitas antiinflamasinya.

\section{Ucapan Terima Kasih}

Penulis mengucapkan terima kasih kepada Fakultas Farmasi Universitas Halu Oleo dan RS PMI Propinsi Sulawesi Tenggara atas fasilitas yang telah diberikan.

\section{Daftar Pustaka}

1. Narande, J. M., Anne W. Dan Adithya Y., Uji Efek Antiinflamasi Ekstrak Etanol Daun Suji (Dracaena Angustifolia Roxb) Terhadap Edema Kaki Tikus Putih Jantan Galur Wistar, Jurnal IImiah Farmasi 2013, 2(3); 2302 - 2493.

2. Riduan R. J., Pengaruh Pemberian Ekstrak Jahe Merah terhadap Gambaran Histopatologi Pankreas yang Diinduksi Aloksan, Majority, 2015, 4(8).

3. Lopez , S. N., Sierra M. G., Gattuso S. J., Furlan R. L. dan Zacchino S. A., An Unusual Homoisoflavanone and Structurally-Related Dihydrochalcone from Polygonum ferrugineum (Polygonaceae), Phytochemistry 2006, 67(6); 2152-2158. 
4. Vlientinck A. J, Van L. H, Totte. J, Lasure. A, Vanden B. D, Rwangabo P. C dan Mvukiyumwami. J., Screening of Hundred Rwandese Medicinal Plants for Antimicrobial and Antiviral Properties, Journal of Ethnopharmacology, 1995, 46 ; 31-47.

5. Johnson, T., CRC Ethnobotany Desk Reference, CRC Press. California. 1998.

6. Sahidin, Nohong, Asrul S., Marianti A., Asep S., Harto W.,Syarulnataqain B., Radical Scavenging Activity Of Triterpene Steroids From Stem Of Polygonum pulchrum $\mathrm{Bl}$, International Journal Of Pharmacy And Pharmaceutical Sciences, 2014, 6; 0975-1491.

7. Poko F.,R., Skrining Fitokimia dan Uji Efek Antihiperlipidemia Ekstrak Etanol Batang Tanaman Bambu-bambu (Polygonum puchrum Blume) pada Mencit Jantan Galur BALB/C, Skripsi 2015, Universitas Halu Oleo, Kendari.

8. Sadino, A., Uji Aktivitas Antimikroba, Antioksidan Dan Toksisitas Akut Ekstrak Etanol Akar, Batang, Daun Dan Bunga Tumbuhan Bambu-Bambu (Polygonum pulchrum Blume), Skripsi 2016, Universitas Halu Oleo, Kendari.

9. Arifah R. N, Nora I, M. Agus W., 2017, Uji Aktivitas Antiinflamasi Ekstrak Kasar Buah Asam Paya (Eleiodoxa conferta (Griff.) Buret) Secara In-Vitro Dengan Metode Stabilisasi Membran HRBC (Human Red Blood Cell), JKK, 2017, 6(1); 2303-1077.

10. Kumar, V., Bhat Z. A., Dinesh. K., Puja. B., Sheela. S., In Vitro Anti-Inflamatory Activity of Leaf Extracts of Basella Alba Linn. Var. Alba, International Journal of Drug Development and Research, 2011, 3(2); 0975-9344.

11. Murningsih, T., dan Ahmad F., Evaluasi Aktivitas Anti-Inflamasi dan Antioksidan Secara In-Vitro, Kandungan Fenolat dan Flavonoid Total Pada Terminalis spp., Berita Biologi, 2016, 15(2); 159-166

12. Wiranto E., Muhamad A. W., Puji A., Aktivitas Antiinflamasi Secara In-Vitro Ekstrak Teripang Butoh Keling (Holothuria leucospilota Brandt) dari Pulau Lemukutan, JKK, 2016, 5(1). 